\title{
Analisis atribut kualitas jasa layanan terhadap kepuasan anggota pada KPRI "KOPPENDA" Kabupaten Klaten
}

\author{
1*Fajar Santoso \\ Kabupaten Sukoharjo, Jawa Tengah \\ *e-mail korespondensi: fajarsantoso1313@gmail.com
}

Universitas Islam Negeri Raden Mas Said Surakarta. Jl. Pandawa, Dusun IV, Pucangan, Kec. Kartasura,

\begin{tabular}{|c|c|}
\hline Article Info & Abstract \\
\hline $\begin{array}{l}\text { Keywords: service } \\
\text { quality, consumer } \\
\text { loyalty, customer } \\
\text { satisfaction. }\end{array}$ & $\begin{array}{l}\text { Service quality can be relied upon as one of the competitive advantages in } \\
\text { increasingly fierce business competition. Excellent service quality is proven to be } \\
\text { able to create consumer loyalty, because excellent quality is often synonymous with } \\
\text { customer satisfaction; and in the end, through customer satisfaction the company } \\
\text { will gain long-term profits. The purpose of this research is to find out: (1) How is } \\
\text { the level of member satisfaction with the service quality of KPRI "KOPPENDA" } \\
\text { Kab. Klaten; (2) What is the most dominant variable in influencing the level of } \\
\text { member satisfaction with the service quality of KPRI "KOPPENDA"Kab. Klaten. } \\
\text { Based on the results of the study, it can be concluded that: (1) The level of member } \\
\text { satisfaction with the service quality of KPRI "KOPPENDA"Kab. Klaten is low; (2) } \\
\text { The most dominant variable in influencing the level of member satisfaction with the } \\
\text { service quality of KPRI "KOPPENDA"Kab. Klaten is Reliability. }\end{array}$ \\
\hline
\end{tabular}

Info Artikel

Abstrak

\begin{tabular}{|c|c|}
\hline $\begin{array}{l}\text { Kata Kunci: } \\
\text { kualitas layanan, } \\
\text { loyalitas konsumen, } \\
\text { kepuasan } \\
\text { konsumen. }\end{array}$ & $\begin{array}{l}\text { Kualitas pelayanan dapat diandalkan sebagai salah satu keunggulan bersaing dalam } \\
\text { persaingan bisnis yang semakin ketat. Kualitas pelayanan prima terbukti mampu } \\
\text { menciptakan loyalitas konsumen, karena kualitas prima seringkali identik dengan } \\
\text { kepuasan pelanggan; dan pada akhirnya melalui kepuasan pelanggan perusahaan } \\
\text { akan memperoleh keuntungan jangka panjang. Tujuan penelitian ini adalah untuk } \\
\text { mengetahui: (1) Bagaimana tingkat kepuasan anggota terhadap kualitas pelayanan } \\
\text { KPRI "KOPPENDA" Kab. Klaten; (2) Variabel apa yang paling dominan } \\
\text { mempengaruhi tingkat kepuasan anggota terhadap kualitas pelayanan KPRI } \\
\text { "KOPPENDA" Kab. Klaten. Berdasarkan hasil penelitian dapat disimpulkan bahwa: } \\
\text { (1) Tingkat kepuasan anggota terhadap kualitas pelayanan KPRI "KOPPENDA" } \\
\text { Kab. Klaten rendah; (2) Variabel yang paling dominan mempengaruhi tingkat } \\
\text { kepuasan anggota terhadap kualitas pelayanan KPRI "KOPPENDA" Kab. Klaten } \\
\text { terpercaya. }\end{array}$ \\
\hline
\end{tabular}

\section{PENDAHULUAN}

Dewasa ini, kualitas jasa layanan semakin mendapatkan perhatian dan menjadi fokus perusahaan. Hal ini disebabkan karena kualitas jasa layanan dapat diandalkan sebagai salah satu keunggulan kompetitif dalam persaingan usaha yang semakin hari semakin ketat. 


\section{Entrepreneurship Bisnis Manajemen Akuntansi (E-BISMA), 2(2), 62-72 \\ Fajar Santoso}

Kualitas jasa layanan yang prima terbukti mampu menciptakan loyalitas konsumen, karena kualitas yang prima sering identik dengan kepuasan pelanggan; dan pada akhirnya, melalui kepuasan pelanggan tersebut perusahaan akan memperoleh keuntungan jangka panjang (Chang et al., 2020; Sabihaini \& Yulianto, 2020).

Total quality service adalah komitmen yang tepat untuk mengoperasionalisasikan konsep yang berfokus pada pelanggan, menetapkan standar persepsi, dan memelihara antusiasme pelanggan pada segala waktu dan pangsa pasar (Stamatis, 1996; Sunarsi, 2020). Total quality service merupakan konsep yang strategik dengan melibatkan manajer dan pekerja/karyawan dengan menggunakan metode kualitatif maupun kuantitatif untuk secara terus-menerus memperbaiki proses organisasi untuk memenuhi dan melampaui kebutuhan pelanggan (Mardianto et al., 2020).

Manajemen selalu berusaha untuk memberikan kualitas jasa layanan yang terbaik bagi pelanggan. Kualitas yang diserahkan oleh manajemen akan menimbulkan persepsi pelanggan terhadap kualitas jasa layanan perusahaan. Seringkali terdapat perbedaan antara kepentingan pelanggan dengan persepsi pelanggan terhadap kualitas yang diberikan oleh manajemen (Yogi \& Putu, 2020). Untuk memastikan apakah manajemen telah memberikan kualitas layanan sesuai dengan kepentingan pelanggan, maka diperlukan adanya evaluasi oleh pelanggan (Veza \& Hernuning, 2020).

Koperasi, sebagai salah satu bentuk perusahaan/badan usaha, perlu juga untuk dievaluasi oleh pelanggannya, dalam hal ini adalah anggota. Evaluasi terhadap kualitas jasa layanan terhadap badan usaha koperasi dapat dilakukan dengan menggunakan dimensi kualitas jasa yang terdiri dari reliability (keandalan), responsiveness (daya tanggap), assurance (jaminan), emphaty (empati), dan tangibles (bukti fisik) (Parasuraman et al., 1985; Almohaimmeed, 2019). Untuk mengevaluasi kualitas jasa layanan yang telah diberikan badan usaha koperasi kepada anggotanya, diperlukan informasi tentang kualitas jasa layanan yang dipersepsikan (perceived service) dan kualitas jasa layanan yang diharapkan (expected service) oleh para anggota. Mereka telah memiliki pengalaman mengkonsumsi jasa layanan koperasi karena mereka menjadi anggota yang tentunya aktif berinteraksi serta bertransaksi dengan koperasi maupun pihak manajemennya, dalam hal ini adalah para pengurus. Dengan demikian mereka tentunya juga memiliki informasi mengenai koperasi dimana mereka menjadi anggotanya. Keduanya sesuai dengan pendapat Zeithaml et al. (1998) tentang faktor-faktor yang mempengaruhi terbentuknya kepentingan akan kualitas. Sedangkan persepsi anggota koperasi terhadap kualitas jasa layanan dapat dibentuk dengan jasa layanan yang telah diserahkan oleh koperasi selama mereka menjadi anggota.

KPRI "KOPPENDA“ Kab. Klaten adalah sebuah badan usaha koperasi yang didirikan oleh para pegawai Kantor Departemen Agama Kab. Klaten. Sebenarnya koperasi ini telah berdiri sejak 20 Juli 1971 dengan badan hukum nomor: 7948/BH/VI/1971 dan dengan nama "Koperasi Pendidikan Agama", namun koperasi ini tidak dapat berkembang, bahkan akhirnya tidak ada kegiatan sama sekali. Baru pada akhir dekade '80-an koperasi ini dihidupkan kembali dengan badan hukum yang lama. Sebagai modal anggota pertama (sejak dihidupkan kembali) adalah seluruh pegawai Kantor Departemen Agama, guru-guru Agama dibawah Depag, dan seluruh kepala KUA se-Kabupaten Klaten, dengan jumlah keseluruhan 192 orang, dan dilantik pada 25 Juni 1987. 


\section{KAJIAN TEORI DAN HIPOTESIS}

Nurvita (2001) dalam penelitiannya menunjukkan bahwa tingkat pelayanan yang diberikan oleh Rumah Sakit Mata Dr. Yap Yogyakarta secara keseluruhan telah memuaskan pelanggan, variabel yang paling dominan dari pelayanan Rumah Sakit Mata Dr. Yap Yogyakarta dalam mempengaruhi kepuasan pelanggan adalah faktor reliability, dan kendala-kendala dalam meningkatkan pelayanan adalah dokter tamu tidak sesuai dengan jadwal pemeriksaan dan karyawan kurang terampil menggunakan peralatan teknologi tinggi. Widarto (2003) dalam penelitiannya mengemukakan bahwa tingkat pelayanan yang telah diberikan oleh PT. Bank BRI Cabang Yogyakarta Katamso Unit Pingit secara keseluruhan tidak ada kesenjangan yang signifikan antara kepentingan dengan kinerja layanan nasabah simpedes di PT. Bank BRI Cabang Yogyakarta Katamso Unit Pingit, yang dibuktikan dari hasil pengujian statisik, dan atribut yang paling dominan adalah dalam mempengaruhi kepuasan konsumen adalah atribut kecepatan dan ketelitian bank. Budiarto (2006) dalam penelitiannya menyimpulkan bahwa hasil analisa gap setiap item pertanyaan terlihat bahwa mahasiswa FTSP program studi Teknik Sipil Universitas Islam Indonesia Yogyakarta, masih merasa kurang puas terhadap pelayanan yang diberikan oleh pihak FTSP program studi Teknik Sipil Universitas Islam Indonesia Yogyakarta, dimana hal ini terlihat dari ratarata gap antara kinerja dan harapan dari sebagian besar item pertanyaan yang bernilai negatif dan hanya dua atribut mempunyai nilai positif, dan analisis gap setiap atribut, dapat diperoleh kesimpulan bahwa atribut item nomor 2 (FTSP UII menyediakan ruang kuliah dengan fasilitas lengkap (misalnya AC, OHP, dan LCD) adalah atribut paling dominan dalam memuaskan kepuasan mahasiswa pada Fakultas Teknik Sipil dan Perencanan program studi Teknik Sipil Universitas Islam Indonesia Yogyakarta.

Tjiptono (1996) mengemukakan bahwa kualitas total suatu jasa terdiri dari beberapa komponen utama, yaitu technical quality, search quality, experience quality, credence quality, functional quality, dan corporate image. Kualitas memliki dua pengertian, yaitu memberikan pelayanan secara langsung dan menawarkan produk yang akan memberikan kepuasan serta memberikan pelayanan secara lengkap (Malik et al., 2020). Menurut Risambessy (2020), kualitas mengimplikasikan memenuhi atau melebihi harapan tentang kecepatan waktu, akurasi pekerjaan, kecepatan tanggapan, dan ujuk kerja. Kalankesh et al. (2020) memberikan pengertian kualitas jasa merupakan tingkat kesempur-naan untuk memenuhi keinginan pelanggan. Kualitas jasa merupakan perbandingan antara jasa yang dirasakan (dipersepsikan) pelanggan dengan kualitas jasa yang mereka harapkan (Parasuraman et al., 1988).

Total quality service merupakan konsep tentang bagaimana menanamkan kualitas pelayanan pada setiap fase penyelenggaraan jasa yang melibatkan personal yang ada dalam organisasi (Handriana, 1998). Parasuraman et al. (1988) menunjukkan terdapat sepuluh faktor utama yang menentukan kualitas jasa, yaitu reliability, responsiveness, competence, access, courtesy, communication, credibility, security, understanding and knowing the customer, dan tangibles. Mengukur kualitas jasa dengan mengetahui perbedaan (gap) antara harapan dengan persepsi pelanggan (Zeithaml, 1998; Khairusy \& Febriani, 2020). 
Kotler \& Keller (2016) dan Idris et al. (2019) mendefinisikan kepuasan sebagai perasaan suka atau kecewa seseorang sebagai hasil dari perbandingan antara persepsi atas kinerja produk dengan harapannya. Pengertian ini bahwa kepuasan merupakan fungsi kinerja yang dipersepsikan dengan harapan. Pontoh et al. (2020) menyatakan bahwa kepuasan atau ketidakpuasan adalah respon seseorang terhadap evaluasi ketidaksesuaian atau diskonfirmasi yang dirasakan antara harapan sebelum (atau norma kinerja lainnya) dan kinerja aktual yang dirasakan setelah pemakaiannya. Prayoga (2020) mengungkapkan bahwa kepuasan adalah evaluasi purna beli dimana alternatif yang dipilih sekurangkurangnya memberikan hasil (outcome) sama atau melampaui harapan pelanggan, sedangkan ketidakpuasan timbul apabila hasil yang diperoleh tidak memenuhi harapan pelanggan.

\section{METODE PENELITIAN}

Penelitian ini merupakan penelitian kuantitatif dan pengambilan sampel dalam penelitian ini menggunakan non-probability sampling (Bajpai, 2018) yaitu dengan kriteria responden yang mudah ditemui. Sampel dalam penelitian ini sebanyak 96 orang responden. Pengambilan data dilakukan dengan menyampaikan kuesioner kepada responden.

Uji validitas dan reliabilitas dilakukan untuk mengetahui kehandalan dan kesahihan kuesioner sebagai instrument penelitian (Bougie \& Sekaran, 2019). Uji servqual dilakukan untuk pengukuran kepuasan pelanggan yang sederhana, mudah digunakan dan diinterpretasikan, dan cara ini dapat digunakan untuk semua pengukuran yang berhubungan dengan kepuasan pelanggan, tidak terkecuali bidang usaha perkoperasian, dalam hal ini yang menyatakan bahwa kepuasan merupakan fungsi disconfirmation antara harapan dan persepsi atas kinerja. Penelitian ini menggunakan servqual untuk mengukur perbedaan (gap) antara harapan anggota terhadap jasa yang ditawarkan oleh koperasi dengan persepsi anggota terhadap kinerja koperasi. Pengukuran dilakukan dengan skala likert dua kutub (Nunnally \& Bernstein, 2017).

\section{HASIL DAN PEMBAHASAN}

Hasil pengujian validitas aspek Harapan, pada lima dimensi kualitas jasa terdapat 30 buah pertanyaan. Dari hasil uji validitas, maka nilai korelasi product moment (r-hasil) yang terendah adalah sebesar 0.0740 sedangkan yang terbesar adalah sebesar 0.6102; sedangkan nilai r-tabel pada tingkat signifikansi 0.05 dengan df 40 adalah sebesar 0.304. Hasil dari pengujian adalah bahwa terdapat 25 buah pertanyaan yang valid dan 5 buah pertanyaan yang tidak valid, sehingga ke lima butir pertanyaan yang tidak lolos uji (tidak valid) tersebut dihilangkan dan tidak diikutsertakan dalam pengujian selanjutnya (pengujian hipotesis). Pengujian validitas aspek Kinerja menunjukkan bahwa semua (30 butir) pertanyaan dinyatakan valid. Namun, karena butir pertanyaan aspek Harapan dan aspek Kinerja saling berpasangan, maka untuk memudahkan penelitian hanya butir-butir pertanyaan yang samasama valid di kedua aspek yang akan digunakan dalam pengujian hipotesis, yaitu sebanyak 25 butir pertanyaan berpasangan. 
Pengujian reliabilitas aspek Harapan dan aspek Kinerja menunjukkan hasil r-alpha Harapan sebesar 0.8788, yang berarti bahwa aspek Harapan berada pada tingkat reliabilitas sangat tinggi. Sementara r-alpha pada aspek Kinerja adalah sebesar 0.9646, yang berarti bahwa aspek Kinerja juga berada pada tingkat reliabilitas sangat tinggi. Jadi kedua aspek Harapan dan Kinerja dapat dikatakan handal (reliable) sehingga layak digunakan untuk pengujian hipotesis. Analisis servqual yang dilaksanakan pada penelitian ini menunjukkan hasil sebagai berikut:

Tabel 1

Analisis Gap Dimensi Tangibles

\begin{tabular}{|c|c|c|c|c|}
\hline No. & Pertanyaan & $\begin{array}{l}\text { Rata-rata } \\
\text { Harapan }\end{array}$ & $\begin{array}{l}\text { Rata-rata } \\
\text { Kinerja }\end{array}$ & $\begin{array}{l}\text { Rata-rata } \\
\text { Gap }\end{array}$ \\
\hline 1 & $\begin{array}{l}\text { Semua jenis produk yang dibutuhkan } \\
\text { anggota selalu tersedia }\end{array}$ & 4.734694 & 4.224492 & -0.510202 \\
\hline 2 & $\begin{array}{l}\text { Anggota tidak pernah mengalami } \\
\text { kesulitan dalam mencari produk yang } \\
\text { dibutuhkan di rak pajangan }\end{array}$ & 4.663265 & 4.142857 & -0.520408 \\
\hline 3 & Karyawan selalu berpenampilan rapi & 4.561224 & 4.285714 & -0.275510 \\
\hline 4 & $\begin{array}{l}\text { Ruang toko KPRI "KOPPENDA" } \\
\text { Kab. Klaten bersih dan nyaman }\end{array}$ & 4.836735 & 4.469377 & -0.367358 \\
\hline 5 & Jumlah karyawan cukup memadai & 4.622449 & 3.693878 & -0.928571 \\
\hline 6 & $\begin{array}{l}\text { KPRI "KOPPENDA" Kab. Klaten } \\
\text { sudah menerapkan sistem komputerisa؛ }\end{array}$ & 4.693878 & 3.785714 & -0.908164 \\
\hline
\end{tabular}

Data diatas menunjukkan bahwa secara keseluruhan hasil analisis menunjukkan bahwa anggota tidak puas terhadap pelayanan yang telah diberikan oleh pihak KPRI "KOPPENDA" Kab. Klaten. Rata-rata Gap menunjukkan bahwa item pertanyaan nomor 5 dan 6 memiliki Gap yang paling besar. Maka yang menjadi prioritas utama bagi pihak KPRI "KOPPENDA" Kab. Klaten adalah untuk menambah jumlah karyawan karena jumlah karyawan yang tersedia saat ini dianggap kurang memadai. KPRI "KOPPENDA" Kab. Klaten sebaiknya juga meningkatkan kualitas fasilitas layanannya khususnya dalam hal komputerisasi, untuk meminimalisasi resiko human error yang mungkin terjadi.

Tabel 2

Analisis Gap Dimensi Reliability

\begin{tabular}{ccccc}
\hline No. & Pertanyaan & $\begin{array}{c}\text { Rata-rata } \\
\text { Harapan }\end{array}$ & $\begin{array}{c}\text { Rata-rata } \\
\text { Kinerja }\end{array}$ & $\begin{array}{c}\text { Rata-rata } \\
\text { Gap }\end{array}$ \\
\hline Setiap kali anggota menghadapi & & & \\
$1 \quad \begin{array}{c}\text { masalah, KPRI "KOPPENDA" Kab. } \\
\text { Klaten akan membantu } \\
\text { menyelesaikannya }\end{array}$ & 4.785714 & 4.071429 & -0.714285 \\
& $\begin{array}{c}\text { Karyawan jarang sekali membuat } \\
\text { kesalahan dalam memberikan } \\
\text { pelayanan kepada anggota }\end{array}$ & 4.683673 & 3.918367 & -0.765306 \\
\hline
\end{tabular}




\begin{tabular}{|c|c|c|c|c|}
\hline 3 & $\begin{array}{l}\text { KPRI "KOPPENDA" Kab. Klaten } \\
\text { menyelesaikan pelayanan untuk } \\
\text { anggota sesuai dengan tempo yang } \\
\text { dijanjikan (tepat waktu) }\end{array}$ & 4.714286 & 4.061224 & -0.653062 \\
\hline 4 & $\begin{array}{l}\text { KPRI "KOPPENDA" Kab. Klaten } \\
\text { jarang sekali membuat kesalahan } \\
\text { dalam melayani transaksi anggotanya }\end{array}$ & 4.836735 & 4.081633 & -0.755102 \\
\hline 5 & $\begin{array}{l}\text { Karyawan mudah ditemui setiap saat } \\
\text { anggota memerlukan bantuan }\end{array}$ & 4.734694 & 3.724490 & -1.010204 \\
\hline
\end{tabular}

Data pada Tabel 2 menunjukkan bahwa secara keseluruhan hasil analisis menunjukkan bahwa anggota tidak puas terhadap pelayanan yang telah diberikan oleh pihak KPRI “KOPPENDA” Kab. Klaten. Rata-rata Gap menunjukkan bahwa item pertanyaan nomor 11 memiliki Gap yang paling besar. Maka yang menjadi prioritas utama bagi pihak KPRI "KOPPENDA" Kab. Klaten adalah untuk memberikan kemudahan bagi anggota untuk bisa menemui karyawan setiap saat anggota memerlukan bantuan. Selain itu juga pihak KPRI "KOPPENDA" Kab. Klaten dan seluruh karyawan hendaknya sebisa mungkin berusaha menghindari kesalahan dalam melayani transaksi anggotanya. Kemungkinan besar hal ini terkait dengan kesimpulan pada dimensi sebelumnya, yaitu bahwa jumlah karyawan yang ada masih kurang memadai, sehingga kapasitas karyawan dalam memberikan pelayanan tidak sebanding dengan jumlah anggota yang harus dilayani. Juga kualitas fasilitas layanan khususnya dalam hal komputerisasi yang masih rendah, sehingga resiko human error yang mungkin terjadi masih sulit untuk diminimalisir.

Tabel 3

Analisis Gap Dimensi Responsiveness

\begin{tabular}{ccccc}
\hline No. & Pertanyaan & $\begin{array}{c}\text { Rata-rata } \\
\text { Harapan }\end{array}$ & $\begin{array}{c}\text { Rata-rata } \\
\text { Kinerja }\end{array}$ & $\begin{array}{c}\text { Rata-rata } \\
\text { Gap }\end{array}$ \\
\hline 1 & $\begin{array}{c}\text { Anggota tidak pernah menunggu } \\
\text { lebih dari lima menit untuk } \\
\text { memperoleh pelayanan }\end{array}$ & 4.693878 & 3.877551 & -0.816327 \\
2 & $\begin{array}{c}\text { Karyawan selalu bersedia } \\
\text { membantu anggota }\end{array}$ & 4.846939 & 4.346939 & -0.500000 \\
$3 \quad \begin{array}{c}\text { petugas keamanan selalu sigap } \\
\text { melayani dan membantu anggota }\end{array}$ & 4.714286 & 4.316327 & -0.397959 \\
4 & $\begin{array}{c}\text { Anggota tidak perlu meminta lebih } \\
\text { dari tiga kali untuk mendapatkan } \\
\text { pelayanan dan bantuan dari }\end{array}$ & 4.561224 & 3.857143 & -0.704081 \\
\hline & karyawan dan petugas keamanan & & & \\
\hline
\end{tabular}

Data Tabel 3 menunjukkan bahwa secara keseluruhan hasil analisis menunjukkan bahwa anggota tidak puas terhadap pelayanan yang telah diberikan oleh pihak KPRI "KOPPENDA" Kab. Klaten. Rata-rata Gap menunjukkan bahwa item pertanyaan nomor 12 memiliki Gap yang paling besar. Maka yang menjadi prioritas utama bagi pihak KPRI "KOPPENDA" Kab. Klaten adalah untuk lebih memperhatikan durasi waktu pelayanan sehingga anggota dapat melakukan transaksi dalam waktu yang relatif singkat. Lagi lagi, 
kemungkinan besar hal ini terkait dengan kesimpulan pada dimensi sebelumnya, yaitu bahwa jumlah karyawan yang ada masih kurang memadai, sehingga kapasitas karyawan dalam memberikan pelayanan tidak sebanding dengan jumlah anggota yang harus dilayani, akibatnya anggota harus mengantre untuk mendapatkan pelayanan. Kualitas fasilitas layanan khususnya dalam hal komputerisasi yang masih rendah menambah parah keadaan, karena tingginya resiko human error yang mungkin terjadi membuat pelayanan per anggota memakan waktu yang cukup lama, padahal antrean masih panjang, akibatnya sebagian anggota sampai harus meminta lebih dari tiga kali untuk mendapatkan pelayanan. Selain itu pihak KPRI “KOPPENDA” Kab. Klaten hendaknya juga memperhatikan kualitas pelayanan dari petugas keamanan (yang sekaligus merangkap sebagai petugas parkir) untuk selalu sigap dan cekatan dalam membantu karyawan melayani dan memberikan bantuan kepada anggota, sehingga diharapkan dapat meminimalisir jumlah anggota yang harus meminta sampai lebih dari tiga kali untuk mendapatkan pelayanan.

Tabel 4

Analisis Gap Dimensi Assurance

\begin{tabular}{|c|c|c|c|c|}
\hline No. & Pertanyaan & $\begin{array}{c}\text { Rata-rata } \\
\text { Harapan }\end{array}$ & $\begin{array}{c}\text { Rata-rata } \\
\text { Kinerja } \\
\end{array}$ & $\begin{array}{c}\text { Rata-rata } \\
\text { Gap }\end{array}$ \\
\hline 1 & $\begin{array}{c}\text { Kualitas pelayanan karyawan } \\
\text { menumbuhkan kepercayaan anggota } \\
\text { terhadap KPRI "KOPPENDA" Kab. } \\
\text { Klaten }\end{array}$ & 4.775510 & 4.295918 & -0.479592 \\
\hline 2 & $\begin{array}{c}\text { Karyawan mampu menjawab semua } \\
\text { pertanyaan anggota }\end{array}$ & 4.734694 & 4.122449 & -0.612245 \\
\hline 3 & $\begin{array}{c}\text { Petugas keamanan bersikap } \\
\text { professional dan memberikan rasa } \\
\text { aman kepada anggota }\end{array}$ & 4.683673 & 4.275510 & -0.408163 \\
\hline 4 & $\begin{array}{l}\text { Karyawan dan petugas keamanan } \\
\text { selalu memberikan pelayanan dengan } \\
\text { ramah dan sopan }\end{array}$ & 4.693878 & 4.102041 & -0.591837 \\
\hline 5 & $\begin{array}{l}\text { Anggota selalu merasa aman dan } \\
\text { nyaman dalam melakukan transaksi }\end{array}$ & 4.653061 & 3.816327 & -0.836734 \\
\hline
\end{tabular}

Data Tabel 4 menunjukkan bahwa secara keseluruhan hasil analisis menunjukkan bahwa anggota tidak puas terhadap pelayanan yang telah diberikan oleh pihak KPRI "KOPPENDA" Kab. Klaten. Rata-rata Gap menunjukkan bahwa item pertanyaan nomor 20 memiliki Gap yang paling besar. Maka yang menjadi prioritas utama bagi pihak KPRI "KOPPENDA" Kab. Klaten adalah untuk memberikan jaminan keamanan dan kenyamanan maksimum bagi anggota dalam melakukan transaksi. Masih, kemungkinan besar hal ini terkait dengan kesimpulan pada dimensi sebelumnya, yaitu bahwa jumlah karyawan yang ada masih kurang memadai, sehingga kapasitas karyawan dalam memberikan pelayanan tidak sebanding dengan jumlah anggota yang harus dilayani, akibatnya anggota harus mengantre untuk mendapatkan pelayanan. Hal ini dapat dipastikan akan mengurangi kenyamanan anggota dalam melakukan transaksi. Kualitas fasilitas layanan khususnya dalam hal komputerisasi yang masih rendah memperburuk keadaan, karena tingginya resiko 


\section{Entrepreneurship Bisnis Manajemen Akuntansi (E-BISMA), 2(2), 62-72 \\ Fajar Santoso}

human error yang mungkin terjadi pasti mempengaruhi rasa aman anggota dalam melakukan transaksi.

Tabel 5

Analisis Gap Dimensi Empathy

\begin{tabular}{|c|c|c|c|c|}
\hline No. & Pertanyaan & $\begin{array}{l}\text { Rata-rata } \\
\text { Harapan }\end{array}$ & $\begin{array}{c}\text { Rata-rata } \\
\text { Kinerja }\end{array}$ & $\begin{array}{l}\text { Rata-rata } \\
\text { Gap }\end{array}$ \\
\hline 1 & $\begin{array}{l}\text { KPRI "KOPPENDA" Kab. Klaten selalu } \\
\text { memberikan informasi terbaru mengenai } \\
\text { produk dan pelayanannya }\end{array}$ & 4.591837 & 3.836735 & -0.755102 \\
\hline 2 & $\begin{array}{l}\text { KPRI "KOPPENDA" Kab. Klaten memiliki } \\
\text { jam pelayanan yang sesuai dengan kebutuhan } \\
\text { anggota }\end{array}$ & 4.551020 & 3.948980 & -0.602040 \\
\hline 3 & $\begin{array}{l}\text { Dalam memberikan pelayanan, karyawan jarang } \\
\text { sekali lupa tidak menyebut nama anggota }\end{array}$ & 4.397959 & 3.959184 & -0.438775 \\
\hline 4 & $\begin{array}{c}\text { Anggota selalu merasa bahwa kepentingannya } \\
\text { lebih diutamakan oleh KPRI "KOPPENDA" } \\
\text { Kab. Klaten }\end{array}$ & 4.622449 & 4.020408 & -0.602041 \\
\hline 5 & $\begin{array}{l}\text { Petugas keamanan selalu siaga untuk } \\
\text { memberikan pelayanan sesuai dengan } \\
\text { kebutuhan anggota }\end{array}$ & 4.591837 & 3.836735 & -0.755102 \\
\hline
\end{tabular}

Data tabel 5 diatas menunjukkan bahwa secara keseluruhan hasil analisis menunjukkan bahwa anggota tidak puas terhadap pelayanan yang telah diberikan oleh pihak KPRI “KOPPENDA” Kab. Klaten. Rata-rata Gap menunjukkan bahwa item pertanyaan nomor 21 memiliki Gap yang paling besar. Maka yang menjadi prioritas utama bagi pihak KPRI "KOPPENDA" Kab. Klaten adalah untuk lebih aktif memberikan informasi terbaru mengenai produk dan pelayanannya kepada anggota. Selain itu juga KPRI "KOPPENDA" Kab. Klaten juga harus memperhatikan pelayanan yang disediakan bagi anggota; serta selalu berusaha untuk lebih memperhatikan kepentingan anggota.

Hasil analisis secara menyeluruh menunjukkan bahwa rata-rata skor perolehan servqual semuanya bernilai skor negatif dimana jika rata-rata skor bernilai negatif berarti anggota merasa tidak atau masih belum puas dengan pelayanan yang telah diberikan oleh pihak KPRI "KOPPENDA" Kab. Klaten. Dari hasil perhitungan yang dilakukan per dimensi kualitas jasa, ternyata yang memiliki pengaruh paling besar terhadap kepuasan anggota yaitu Reliability dengan rata-rata paling besar yaitu -0.77959; sedangkan untuk keempat atribut yang lain, yaitu: Responsiveness (-0.60459), Empathy (-0.59592), Assurance (-0,58571), serta Tangibles (-0.58503) memiliki nilai rata-rata yang lebih kecil.

Hasil senada ditunjukkan oleh Haladi (2018) yang menunjukkan bahwa kualitas layanan berpengaruh positif terhadap kepuasan konsumen. Hasil serupa juga disampaikan oleh Yehezkiel dan Saryadi (2017) yang menyimpulkan bahwa kualitas layanan berpengaruh positif terhadap kepuasan konsumen. Penelitian selanjutnya yang dilakukan oleh Marati (2016) menunjukkan hasil senada bahwa kualitas layanan berpengaruh signifikan terhadap kepuasan pelanggan. Penelitian dengan hasil serupa juga telah dilakukan 
oleh Nisrina et al. (2019), Rianasari (2019), Maydiana (2019), Hardiyanto (2019), Walukow et al. (2019), serta Utami dan Sharif (2020).

\section{KESIMPULAN DAN SARAN}

Hasil analisis gap menunjukkan bahwa anggota merasa tidak atau belum puas terhadap pelayanan yang telah diberikan oleh pihak KPRI "KOPPENDA" Kab. Klaten. Hal ini terlihat dari nilai rata-rata Gap antara Harapan dan Kinerja dari seluruh butir pertanyaan bernilai negatif. Hasil setiap dimensi kualitas jasa menunjukkan bahwa ternyata yang memiliki pengaruh terbesar terhadap kepuasan anggota yaitu dimensi Reliability dengan nilai Rata-rata Gap sebesar. -0.77959; kemudian diikuti Responsiveness dengan nilai Ratarata Gap sebesar -0.60459; Empathy dengan nilai Rata-rata gap sebesar -0.59592; Assurance dengan nilai Rata-rata Gap sebesar -0.58571; dan Tangibles dengan nilai rata-rata sebesar 0.58503. Dari sini bisa dilihat bahwa pihak KPRI "KOPPENDA" Kab. Klaten seharusnya lebih fokus ke dimensi Reliability (keandalan) dan diikuti dengan perbaikan kinerja terhadap keempat dimensi yang lain. Saran untuk penelitian selanjutnya adalah meneliti tentang faktor-faktor lain yang mempengaruhi pelayanan, misalnya kinerja karyawan dan motivasi kerja.

\section{DAFTAR PUSTAKA}

Almohaimmeed, B. M. (2019). Internal service quality and external service quality using two versions of SERVQUAL scale: An empirical evidence from five malls in the capital city of Saudi Arabia. Verslas: teorija ir praktika, 20(1), 158-169.

Bajpai, N., (2018), Business Research Methods, Second Edition, Pearson.

Bougie, R., \& Sekaran, U. (2019). Research methods for business: A skill building approach. John Wiley \& Sons.

Budiarto, A., (2006), Analisis Atribut Kualitas Layanan Terhadap Kepuasan Konsumen Pada Perguruan Tinggi Studi Fakultas Teknik Sipil Dan Perencanaan Universitas Islam Indonesia Yogyakarta. Tesis S2 UII Yogyakarta.

Chang, K. T., Chakraborty, N. M., Kalamar, A. M., Hameed, W., Bellows, B., Grépin, K. A., Gul, A.X., Bradley, S.E., Atuyambe, L.M., \& Montagu, D. (2020). Measuring service quality and assessing its relationship to contraceptive discontinuation: A prospective cohort study in Pakistan and Uganda. Global Health: Science and Practice, 8(3), 442-454.

Haladi, A. H., (2018), Pengaruh Kualitas Layanan terhadap Kepuasan Pelanggan Jasa Transportasi Gojek di Kota Surabaya, Jurnal Akuntansi AKUNESA, 7(1), 1-17.

Handriana, T., (1998), Analisis Perbedaan Harapan Kualitas Jasa Pada Lembaga Pendidikan Tinggi di Surabaya, Tesis S2 UII Yogyakarta.

Hardiyanto, S. M., (2019), Pengaruh Kualitas Layanan dan Harga terhadap Kepuasan Pelanggan Pengguna Jasa PT. Kereta Api Indonesia DAOP VIII Jurusan Surabaya Malang, Jurnal Pendidikan Tata Niaga, 7(2), 440-444.

Idris, I., Sari, P. D., Ali, Y., Aisyah, S., \& Hadi, A. S. (2019). The Effect of taxi bike Service Quality on Customer Satisfaction among Students. In ICASI 2019: Proceedings of The 2nd International Conference On Advance And Scientific Innovation, ICASI 2019, 18 July, Banda Aceh, Indonesia (p. 1). European Alliance for Innovation. 


\section{Entrepreneurship Bisnis Manajemen Akuntansi (E-BISMA), 2(2), 62-72 \\ Fajar Santoso}

Kalankesh, L. R., Nasiry, Z., Fein, R. A., \& Damanabi, S. (2020). Factors influencing user satisfaction with information systems: a systematic review. Galen Medical Journal, 9, $1-9$.

Khairusy, M. A., \& Febriani, R. (2020). Pengaruh Kualitas Produk dan Kualitas Pelayanan Terhadap Kepuasan Pelanggan (Survey pada Pelanggan KFC Store Merdeka Bandung). Jurnal Manajemen Dan Bisnis, 2(01), 19-30.

Kotler, P., \& Keller, K. L. (2016). A framework for marketing management. Boston, MA: Pearson.

Malik, S. A., Akhtar, F., Raziq, M. M., \& Ahmad, M. (2020). Measuring service quality perceptions of customers in the hotel industry of Pakistan. Total Quality Management \& Business Excellence, 31(3-4), 263-278.

Marati, N. C., (2016), Pengaruh Kualitas Layanan dan Harga terhadap Kepuasan Pelanggan Jasa Transportasi Ojek Online (Studi pada Konsumen Gojek di Surabaya), Jurnal Pendidikan Tata Niaga, 4(3), 1-12.

Maydiana, L., (2019). Pengaruh Kualitas Jasa Layanan terhadap Kepuasan Pelanggan pada Jasa Cuci Motor Mandiri, Jurnal Pendidikan Tata Niaga, 7(2), 444-450.

Mardianto, Nasution, I., \& Ningrum, U. P. (2020). Application of Total Quality Services (TQS) in Course Institutions and Training Main Jaya Deli Serdang District. International Journal of Latest Research in Humanities and Social Science (IJLRHSS), 3(6), 32-36.

Nisrina, M. A., Ramdan, A. M., dan Mulia, Faizal, (2019), Kekuatan Nilai Emosional dan Kualitas Pelayanan terhadap Kepuasan Konsumen pada Perusahaan Jasa Ekspedisi, EJurnal Ekonomi dan Bisnis Universitas Udayana, 8(6, 537-549.

Nunnally, J. C., \& Bernstein, I. H. (2017). Psychometric theory (3rd ed.). New York, NY: McGraw-Hill.

Nurvita, H., (2001), Analisis Kepuasan Pelanggan Terhadap Pelayanan di Rumah Sakit mata dr. Yap Yogyakarta, Tesis S2 UII Yogyakarta.

Parasuraman, A., Zeithaml, V. A., \& Berry, L. L. (1985). A conceptual model of service quality and its implications for future research. Journal of marketing, 49(4), 41-50.

Passath, T., \& Mertens, K. (2019). Decision making in lean smart maintenance: criticality analysis as a support tool. IFAC-PapersOnLine, 52(10), 364-369.

Pontoh, B., Hermanto, B., dan Apituley, J., (2020), Pengaruh Kualitas Layanan terhadap Kepuasan Pelanggan pada Pengguna Jasa Transportasi Online Grab (Studi pada Pelanggan Grabcar di Kecamatan Tombulu Kabupaten Minahasa), Manajemen dan Kewirausahaan, 1(2).

Prayoga, I. M. S. (2020). Pengaruh Kualitas Jasa Dan Kepuasan Pelangan Pada Niat Pemakaian Ulang Jasa Bengkel Honda. JUIMA: JURNAL ILMU MANAJEMEN, 10(1), 67-73.

Rianasari, V., (2019), Analisis Pengaruh Tingkat Kualitas Pelayanan Jasa Puskesmas terhadap Kepuasan Pasien (Studi Kasus pada Puskesmas Kotagede I), Jurnal E-BIS, 3(1): 76-83.

Risambessy, A. (2020). Pengaruh Kualitas Jasa terhadap Kepuasan Pengguna Jasa Kesehatan (Studi pada Pasien Rawat Inap Rumah Sakit Harapan Kita Ambon). Jurnal Aplikasi Manajemen, 6(1), 56-72.

Sabihaini, S., \& Yulianto, A. (2020). Analisis Quality Function Deployment (QFD): The Voice of Customer untuk Menghasilkan Kualitas Jasa (Studi kasus pada PT. Kereta Api Indonesia). Media Riset Bisnis \& Manajemen, 3(2), 184-201. 
Sunarsi, D. (2020). Pengaruh Bauran Pemasaran Dan Kualitas Pelayanan Terhadap Kepuasan Konsumen Pada Giant Dept Store Cabang BSD Tangerang. E-Mabis: Jurnal Ekonomi Manajemen dan Bisnis, 21(1), 7-13.

Stamatis, D.H., (1996), Total Quality service, St Lucie Press, U.S.A.

Tjiptono, F., (1996), Manajemen Jasa. Yogyakarta: Penerbit Andi.

Utami, A. D., dan Sharif, O. O., (2020), Analisis Kualitas Layanan Jasa terhadap Kepuasan Konsuen (Studi Kasus Grab di Kota Bandung), Jurnal Mitra Manajemen, 4(2), 184194.

Veza, O., \& Hernuning, N. (2020). Analisis Tingkat Kepuasan Pelanggan terhadap Pelayanan Online Shop GIC. Jurnal Industri Kreatif (JIK), 4(01), 37-44.

Walukow, D. N., Rumayar, A. A., dan Kandou, G. D., (2019), Hubungan Kualitas Jasa Pelayanan Kesehatan dengan Kepuasan Pasien di Puskesmas Pineleng Kabupaten Minahasa, Kesmas, 8(4), 62-66.

Widarto, K. (2003), Analisis Atribut Mutu Layanan Pada Nasabah Simpedes Di PT. Bank BRI Cabang Yogyakarta Katamso Unit Pingit. Tesis S2 UII, Yogyakarta.

Yehezkiel, T. C., dan Saryadi, (2017), Pengaruh Kualitas Layanan terhadap Kepuasan Konsumen Pengguna Jasa Transportasi Gojek di Jakarta, Jurnal Ilmu Administrasi Bisnis, 6(3), 645-656.

Yogi, S. I. P., \& Putu, C. N. L. (2020). Pengaruh Lokasi Usaha Dan Kualitas Jasa Terhadap Kepuasan Pelanggan Pada Usaha Jasa Laundry Di Wilayah Pejeng Tahun 2019: The Influence of Bussines Location and Service Kuality on Castomer Statisfaction with Laundry Service in the Pejeng region in year 2019. Social Studies, 8(2), 1-8.

Zeithaml, A.V., Berry L.L., dan Parasuraman, A., (1993), The Nature and Determinants of Customer Expectations of Services, Journal of Academy Marketing Science, 21, 1-12. 